\title{
PENGARUH KUALITAS PELAYANAN CUSTOMER SERVICE TERHADAP KEPUASAN PENGGUNA KARTU INDOSAT OOREDOO PADA PT. INDOSAT OOREDOO GIANYAR
}

\author{
Dewa Ketut Mahardika ${ }^{1}$ \\ I Gst Bgs Wirya Gupta ${ }^{2}$ \\ ${ }^{1,2}$ Fakultas Ekonomi Universitas Ngurah Rai, Denpasar, Bali
}

\begin{abstract}
ABSTRAK
Penelitian ini bertujuan untuk mengetahui pengaruh kualitas pelayanan customer service terhadap kepuasan pengguna kartu Indosat Ooredoo pada PT. Indosat Ooredoo Gianyar. Penelitian ini dilakukan di PT. Indosat Ooredoo Gianyar. Jumlah sampel yang diambil sebanyak 99 orang, dengan metode random sampling. Pengumpulan data dilakukan dengan cara observasi, wawancara, kuesioner, dan studi pustaka. Regresi linier sederhana, analisis determinasi, dan uji t-test merupakan teknik analisis yang dipergu nakan. Dari analisis yang dilakukan, didapat hasil antara lain: dari hasil regresi linier sederhana diperoleh persamaan $\mathrm{Y}=2,973+0,063 \mathrm{X}$ ini menunjukkan bahwa kualitas pelayanan sebesar $=0$, maka kepuasan pengguna kartu Indosat Ooredoo pada PT. Indosat Ooredoo Gianyar sebesar 2,973 satuan. Dari regresi linier sederhana tersebut juga dapat dilihat bahwa koefisien sebesar 0,063. Dari hasil analisis determinasi sebesar $18,7 \%$, yang artinya bahwa kualitas pelayanan berpengaruh sebesar $18,7 \%$ terhadap kepuasan pengguna kartu Indosat Ooredoo pada PT. Indosat Ooredoo Gianyar, dan sisanya sebesar 81,3\% dipengaruhi variabel lain yang tidak diteliti. Dari hasil uji t (t test), menunjukkan thitung $(4,718)>$ dari $t$ tabel $(1,661)$ yang artinya Ho ditolak dan hipotesis terbukti signifikan. Untuk meningkatkan kepuasan konsumen hendaknya PT. Indosat Ooredoo Gianyar meningkatkan a spek -aspek kualita s pela ya nan.
\end{abstract}

Kata kunci : Kualitas Pelayanan dan Kepuasan Konsumen

\section{ABSTRACT}

This study aims to determine the effect of customer service on customer satisfaction Indosat Ooredoo card at PT. Indosat Ooredoo Gianyar. This research was conducted at PT. Indosat Ooredoo Gianyar. The number of samples has taken as many as 99 people, with random sampling method. The data were collected by observation, interview, questionnaire, and literature study. Simple linear regression, determination analysis, and t-test are the analytical techniques used. $Y=2,973+0,063 X$ shows service quality equal to 0 , hence the satisfaction of Indosat Ooredoo card user at PT. Indosat Ooredoo Gianyar is 2,973 units. From this simple linear regression can also be seen with another that is equal to 0.063. From the analysis of determination of $18.7 \%$, which means the quality of service $18.7 \%$ to the satisfaction of Indosat Ooredoo card users at PT. Indosat Ooredoo Gianyar, and the remaining $81.3 \%$ bear other variables that are not researched. From result of t test (t test), show t count (4,718)> fromt table (1,661) which means Ho rejected and hypothesis proved significant. To increase customer satisfaction PT. Indosat Ooredoo Gianyar improves aspects of service quality.

Keywords: Service Quality and Consumer Satisfaction 


\section{PENDAHULUAN}

Jumlah pengguna layanan ponsel menurut laporan The International Telecommunication Union di akhir 2009, mencapai 4,6 milyar akun, sebuah hasil studi terhadap 2000 sample, mengungkapkan bahwa penggunaan ponsel lebih banyak untuk hubungan pribadi dan keluarga yaitu $61 \%$, sementara untuk keperluan pekerjaan hanya 21\% (Bittman et all, 2001). Di Indonesia penggunaan layanan telekomunikasi pada tahun 2010 diperkirakan mencapai angka 133 juta (detiknet.com). Jumlah pelanggan operator telekomunikasi Indonesia mencapai 240 juta pelanggan pada tahun 2010 yang dilayani 10 operator telekomunikasi (Wikipedia.org).

Terdapat banyak perusahaan telekomunikasi yang bermunculan di Indonesia dengan keunggulan masingmasing produk dan penawaran yang menggiurkan konsumen, mulai dari sms murah sampai video call dengan internetan murah.Kondisi persaingan yang sangat ketat ini megharuskan perusahaanmemprioritaskan pelayanan dan kepuasan pelanggan. Pelayanan adalah setiap tindakan atau kegiatan yang dapat ditawarkan oleh satu pihak ke pihak lain yang pada dasarnya tidak terwujud dan tidak mengakibatkan kepemilikan suatu apapun, jika pelayanan yang diberikan baik dan memuaskan sesuai dengan standar yang berlaku dan dapat menjawab semua pertanyaan pelanggan akan menghasilkan kepuasan yang tinggi dari pelanggan, kepuasan pelaggan adalah tingkat perasaan seseorang setelah membandingkan kinerja yang dirasakan dibandingkan dengan harapanya (Kotler, 2000:45).
Pertumbuhan operator selular tergolong pesat di Indonesia. Kalau dibagiberdasarkan platform yang digunakan, pemakai GSM selular sebanyak $88 \%$,CDMA selular 3\%, dan CDMA fixed wireless access (FWA) 9\%. Namun darisepuluh operator itu hanya 3 operator yang memiliki pangsa pasar lebih dari 5\%yaitu Telkomsel, Indosat Ooredoo dan Excelcomindo.Kompetisi di telepon selular telah terjadi lebih intensif. PT Telkomsel danPT. Indosat Ooredoo memiliki cakupan nasional, sedangkan Exelcomindo memilikicakupan hampir di seluruh wilayah kecuali Maluku, dan Fren dari Mobile-8 hanyaterdapat di pulau Jawa, Madura dan Bali.

PT. Indosat Ooredoo, Tbk adalah salah satu perusahaan penyedia jasa telekomunikasi seluler yang berkomitmen memberikan layanan yang terbaik bagi pelanggannya.Salah satu produk dari PT.Indosat Ooredoo, Tbk adalah Indosat Ooredoo.Indosat Ooredoo menawarkan produk dan jasa yang menawarkan kemudahan, akses ke dunia digital yang lebih baik, serta terjangkau, menghubungkan lebih dan akses yang lebih, Indosat Ooredoopasarnya memang difokuskan untuk anak muda dan pekerja.Pasar anak muda merupakan pasar seluler terbesar kedua setelah pasar pekerja. Hal ini bukan berarti kemenangan untuk salah satu produk Indosat Ooredoo, dengan adanya pernyataan yang beredar di masyarakat "harga menentukan kualitas" ini menimbulkan fenomena yang berbanding lurus yakni timbulnya keluhan di berbagai bidang dari pelanggan, terlihat banyaknya keluhan pelanggan yang terjadi, beberapa keluhan yag banyak terjadi yaitu kualitas koneksi, sistem billing, dan tidak bisa mengakses layanan. Keluhan-keluhan 
tersebut dapat mengakibatkan penurunan jumlah pelanggan perusahaan, oleh karena itu PT. Indosat Ooredoo perlu terus meningkatkan kualitas produk sehingga hal tersebut dapat meningkatkan kepuasan pelanggan.

Pengukuran kepuasan bagi pelanggan dapat dilakukan dengan cara melakukan pengukuran atas dimensi Kualitas Layanan (Service Quality), yang menurut Parasuraman, Berry dan Zeithaml (1994) yang dikutip oleh Zeithaml dan Bitner (2000:82) dikatakan sebagai model ServQual, yang meliputi dimensi Tangible, Empathy, Reliability, Responsiveness dan Assurance.Tangiblemeliputi penampilan fisik (pegawai, kantor, teknologi dan sebagainya) dari perusahaan yang mendukung terwujudnya kepuasan, empathyyaitu perhatian (kepedulian) perusahaan secara individual terhadap pelanggannya, seperti kemudahan menghubungi perusahaan, layanan keluhan pelanggan. Reliability adalah kemampuan produk untuk memuaskan pelanggan sesuai dengan jaminan perusahaan.Responsiveness menyangkut kesediaan staf/karyawan untuk membantu kesulitan yang dihadapi pelanggan maupun kecepat-tanggapan karyawan dalam melayani pelanggan.Assuranceaspek yang dilihat adalah kepercayaan pelanggan terhadap perusahaan yang dapat diukur salah satunya dengan tingkat keterampilan dalam memberikan layanan maupun pengetahuan karyawan.

PT. Ind osat Ooredoo Gianyar yang berlokasi dijalan By. Pass Dharma Giri Gianyar selain menjual berbagai produk Indosat Ooredoo seperti kartu perdana, paket data internet, dan penjualan pulsa, juga melayani penggantian kartu atau charge card. Banyaknya pelanggan yang datang dengan berbagai kepentingan, sudah tentu ada keluhan-keluhan dari konsumen salah satunya waktu pelayanan yang lebih lama pada jam-jam sibuk.PT. Indosat Ooredoo Gianyar sudah semestinya memberikan pelayanan yang memuaskan terhadap pelanggan atau konsumen yang datang.

Kualitas jasa pelayanan yang diberikan oleh PT. Indosat Ooredoo Gianyar berpengaruh langsung terhadap kepuasan konsumennya.Dimana konsumen pada umumnya mengharapkan produk berupa barang dan jasa yang dikonsumsi dapat diterima dan dinikmati dengan pelayanan yang memuaskan.Namun dengan berjalannya waktu PT. Indosat Ooredoo Gianyar mengalami tingkat penurunan jumlah service dengan selisih yang cukup besar dari bulan ke bulannya.

Mengingat adanya persaingan provider yang semakin banyak, sebagai salah satu provider operator selular Indosat Ooredoo memprioritaskan kualitas pelayanan terhadap pelanggan dan pengguna kartu Indosat Ooredoo, adapun beberapa upaya untuk meningkatkan kinerja karyawan seperti training dan pelatihan-pelatihan untuk menanggulangi masalah terkait kartu Indosat Ooredoo, segala peningkatan telah dilakukan terhadap tingkat kepuasan pengguna kartu Indosat Ooredoo Gianyar.

Karena pentingnya pelayanan serta kepuasan pelangggan, maka PT. Indosat Ooredoo dituntut utuk secara terus menerus meningkatkan kualitas pelayanan kepada pelanggan, tugas tersebut direpresentasikan oleh kemampuan Customer Service dalam melayani customer. Customer service adalah setiap kegiatan yang ditujukan untuk memberikan kepuasan melalui pelayanan yang diberikan seseorang kepada kliennya dalam 
menyelesaikan masalah dengan memuaskan.Pelayanan yang diberikan termasuk menerima keluhan atau masalah yang sedang dihadapi.Customer servicerepresentative dituntut untuk selalu berhubungan dengan pelanggan dengan memberikan pelayanan yang memuaskan kepada pelanggan.

Berdasarkan uraian dalam latar belakang masalah diatas, maka rumusan masalah dalam penelitian ini adalah: Bagaimakah pengaruh kualitas pelayanan customer service terhadap kepuasan pengguna kartu Indosat Ooredoo pada PT. Indosat Ooredoo Gianyar?

\section{METODE PENELITIAN}

Penelitian ini dilakukan padaPT. Indosat Ooredoo Gianyar yang terletak di Jalan By. Pass Dharma Giri Gianyar.Yang menjadi obyek penelitian ini adalah dimensi kualitas pelayanan customer serviceyang terdiri dari tangible, reliability, responsiveness, assurance dan empathy terhad ap tingkat kepuasan konsumen pengguna kartu Indosat Ooredoo dalam menggunakan kartu Indosat Ooredoo di PT. Indosat Oored oo Gianyar. Pemilihan PT. Indosat Ooredoo Gianyar, dilandasi pertimbangan selain pengguna kartu Indosat Ooredoo di Indonesia menduduki posisi ketiga terbanyak, dengan banyaknya bermunculan produk pesaing dari kartu selular lain, menyebabkan semakin ketatnya persaingan yang dihadapi oleh PT. Indosat Ooredoo pada umumnya dan PT. Indosat Ooredoo di Kabupaten Gianyar pada khususnya untuk bertahan dalam persaingan produk.

Penelitian ini menggunakan data skunder dan data primer yang didapat dengan melakukan observasi langsung ke tempat penelitian. Selain itu pengumpulan data juga dilakukan dengan cara wawancara, kuesioner, dan studi pustaka. Untuk menganalisis data dipergunakan teknik analisis kuantitatif antara lain regresi linier sederhana, analisis determinasi, dan uji t-test.Serta analisis kualitatif yang bersifat melengkapi analisis kuantitatif yang berbentuk penjelasan-penjelasan terhadap berbagai nilai yang diperoleh melalui analisis kuantitatif.Analisis ini dilakukan dengan teknik deskriptif yaitu penjelasan serta interprestasi untuk temuan dalam analisis kuantitatif.

\section{HASIL DAN PEMBAHASAN}

Analisis Regresi Linier Sederhana

Analisis regresi linier sederhana digunakan untuk mengetahui besarnya pengaruh antara kualitas pelayanan terhadap kepuasan konsumen pada PT. Indosat Oored oo Gianyar. Berdasarkan hasil analisis dengan menggunakan program SPSS version 22.0 for windows dapat diketahui bahwa nilai konstanta $a=2,973$ dan nilai koefisien regresi atau garis regresi $b=0,063$ sehingga diperoleh persamaan regresi linier sederhana sebagai berikut :

\section{2,973+0,063X}

$$
\mathrm{Y}=\mathrm{a}+\mathrm{bX} \text { atau } \mathrm{Y}=
$$

Sehingga memberikan informasi sebagai berikut :

$\begin{aligned} \text { 1) } \mathrm{a}=2,973, & \text { artinya bahwa apabila } \\ & \text { tidak ada terdapat } \\ & \text { variabel } \text { kualitas } \\ & \text { pelayanan atau nilainya } \\ & \text { nol, maka nilai } \\ & \text { kepuasan konsumen } \\ & \text { adalah rata-rata sebesar } \\ & 2,973 \text {. } \\ \text { 2) } \mathrm{b}=0,063, & \text { artinya apabila variabel } \\ & \text { kepuasan konsumen } \\ & \text { dianggap nol, maka } \\ & \text { meningkatnya skor } \\ & \text { kualitas pelayanan }\end{aligned}$




$\begin{array}{lr}\text { sebesar satu satuan, } & \text { oleh } \\ \text { diikuti } & \text { nilai } \\ \text { meningkatnya } & \text { konsumen } \\ \text { kepuasan } & \text { kebesar rata-rata } 0,063 .\end{array}$

Jadi dengan demikian, maka dapat dinyatakan bahwa ada pengaruh yang positif antara kualitas pelayanan terhadap kepuasan konsumen pada PT. Indosat Oored oo Gianyar.

\section{Analisis Determinasi}

Untuk mengetahui besarnya kontribusi variabel kualitas pelayanan (X) terhadap kepuasan konsumen (Y) pada PT. Indosat Ooredoo Gianyar. Maka digunakan analisis determinasi, dengan rumus :

$\mathrm{D}=\mathrm{r}^{2} \mathrm{x} 100 \%$. Sehingga besarnya determinasi yang diperoleh adalah :

$$
\begin{aligned}
\mathrm{D} & =(0,432)^{2} \times 100 \% \\
& =0,187 \times 100 \% \\
& =18,7 \%
\end{aligned}
$$

Ini berarti kontribusi kualitas pelayanan terhadap kepuasan konsumen pada PT. Indosat Ooredoo Gianyar sebesar $18,7 \%$ sedangkan sisanya sebesar $81,3 \%$ merupakan kontribusi dari variabel lain yang tidak diteliti.

\section{Analisis Uji t (t-test)}

Analisis uji-t (t-test) digunakan untuk menguji signifikansi pengaruh kualiatas pelayanan terhadap kepuasan konsumen, adalah pengaruh yang positif dan signifikan atau diperoleh secara kebetulan saja.

Langkah-langkah pengujian hipotesisnya adalah sebagai berikut

1) Perumusan hipotesis

Hipotesis yang diuji adalah pengaruh variabel bebas kualitas pelayanan $(\mathrm{X})$ terhadap variabel terikat kepuasan konsumen (Y) pada PT. Indosat Oored oo Gianyar.
Sesuai dengan hipotesis tersebut maka dirumuskan hipotesis sebagai berikut :

Ho: $\beta=0$, yang berarti bahwa tidak ad a pengaruh yang positif dan signifikan dari kualitas pelayanan terhadap kepuasan konsumen pada PT. Indosat Ooredoo Gianyar.

Ha : $\beta>0$, yang berarti bahwa ada pengaruh yang positif dan signifikan dari kualitas pelayanan terhadap kepuasan konsumen pada PT. Indosat Ooredoo Gianyar.

2) Penentuan t-tabel

Sesuai dengan hipotesis alternatif (Ha) yang menyatakan $\beta>$ 0 , atau ada hubungan yang positif dan signifikan antara kualitas pelayanan terhadap kepuasan konsumen, maka dalam pengujian ini digunakan uji satu sisi, yaitu uji sisi kanan dengan rumus $t_{\text {tabel }}=$ $t_{(\alpha, d f) .} \alpha=$ alpha (taraf signifikan) yang digunakan $=0,05$ dan $\mathrm{df}$ (degrees of freedom=derajat bebas) dapat dicari dengan rumus $\mathrm{df}=\mathrm{n}-\mathrm{k}$. Untuk $\mathrm{n}=99$ dan $\mathrm{k}=2$, maka besarnya $\mathrm{df}=\mathrm{n}-\mathrm{k}=99-2=97$, sehingga besarnya $\mathrm{t}$-tabel $=\mathrm{t}(\alpha . \mathrm{df})$ yang dicari adalah $t(0,05: 97)$ yang terdapat pada Tabel Distribusi $\mathrm{t}$ adalah sebesar 1,661.

3) Perhitungan t-hitung

Berdasarkan hasil analisis dengan menggunakan Program SPSS Version22.0 for Windows besarnya t-hitung adalah sebesar 4,718.

4) Kriteria penerimaan atau penolakan hipotesis 
Adapun kriteria penerimaan atau penolakan hipotesis yang diajukan di atas adalah sebagai berikut :

a. Jika t-hitung $\leq \mathrm{t}$-tabel, maka Ho diterima atau Ha ditolak.

b. Jika t-hitung > t-tabel, maka Ho ditolak atau Ha diterima.

5) Menggambarkan

Penerimaan dan Penolakan

Hipotesis

Untuk membuktikan Ho diterima atau ditolak, sesuai dengan hipotesis yang diajukan, maka dipergunakan uji satu sisi yaitu sisi kanan, yang dapat digambarkan dalam sebuah kurva normal penerimaan dan penolakan hipotesis sebagai berikut :

Gambar 1.1 Kurva Normal Penerimaan dan Penolakan Hipotesis dengan Uji-t Pengaruh Kualitas Pelayanan Terhadap Kepuasan Konsumen

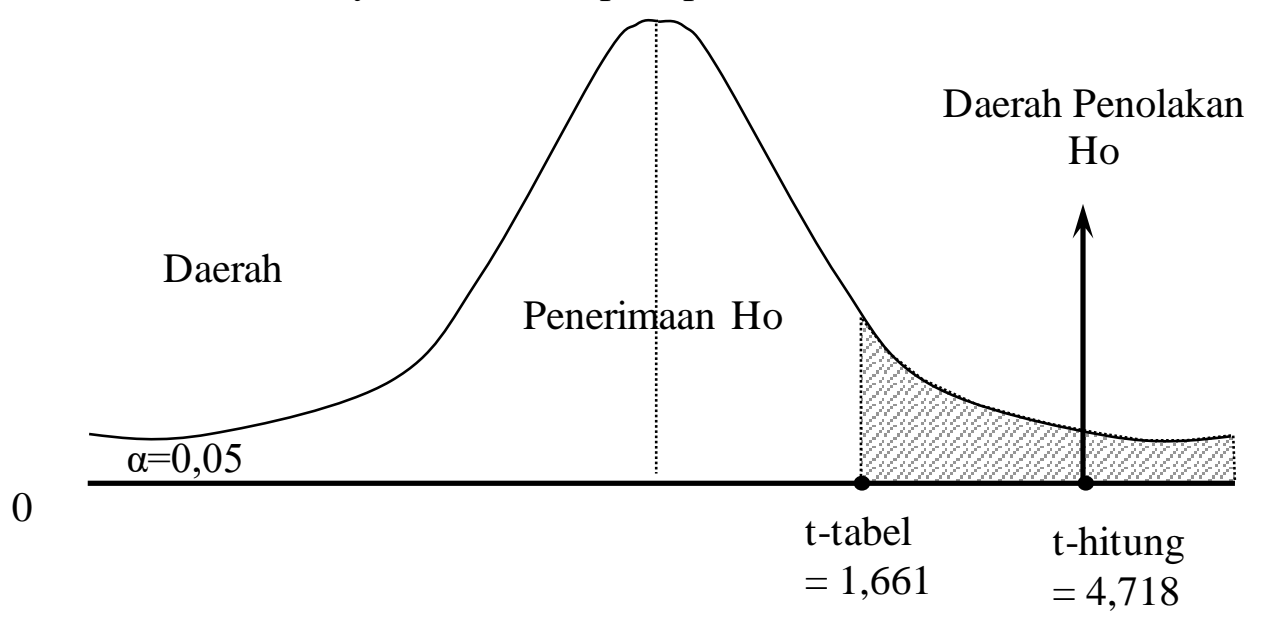

6) Kesimpulan

Berdasarkan gambar 1.1 di atas menunjukan bahwa nilai $t_{\text {hitung }}$ diperoleh sebesar 4,718 sedangkan nilai $t_{\text {tabel }}$ sebesar 1,661. Ternyata nilai $t_{\text {hitung }}=(4,718)$ lebih besar dari tabel $=(1,661)$ berad a pada daerah penolakan Ho. Oleh karena itu, Ho ditolak dan Ha diterima. Hal ini berarti bahwa hipotesis yang diajukan yang berbunyi "Terdapat pengaruh yang positif dan signifikan antara kualitas pelayanan terhadap kepuasan konsumen" terbukti.
Berdasarkan keseluruhan hasil pengujian di atas, dengan taraf signifikan yang digunakan $=0,05$ dan pada derajat bebas $=97$, maka diperoleh besarnya t-hitung adalah sebesar 4,718 dan besarnya t-tabel adalaht $(0,05: 97)=1,661$. 
pada PT. Ind osat Ooredoo Gianyar, dan sisanya sebesar $81,3 \%$ dipengaruhi variabel lain yang tidak diteliti.

3. Dari hasil uji $\mathrm{t}(\mathrm{t}$ test), menunjukkan t hitung $(4,718)>$ dari t tabel $(1,661)$ yang artinya Ho ditolak dan hipotesis terbukti signifikan.

\section{Saran}

1. Mengingat kualitas pelayanan berpengaruh signifikan terhadap kepuasan konsumen, maka pihak PT. Indosat Ooredoo Gianyarperlu memperhatikan kualitas pelayanannya. Lain daripada itu perusahaan perlu menjaga brand image perusahaan sehingga diharapkan akan memberikan nilai tambah serta membawa citra baik terhadap PT. Indosat Ooredoo Gianyar.

Hendaknya pihak perusahaan perlu memberikan semacam pelatihan kepada seluruh karyawannya mengenai kualitas pelayanan, keramahan, dan empati kepada konsumen serta fasilitas penunjang perlu ditambah seperti sarana wifi gratis dan pendingin ruangan, sehingga konsumen merasa nyaman saat menunggu antrean pelayanan.

\section{REFERENSI}

Adiyani.2016. Pengaruh Kualitas Pelayanan Terhadap Kepuasan Pengunjung Pada Objek Wisata PT. Taman Nusa Gianyar.Skripsi. Fakultas Ekonomi Universitas Ngurah Rai Denpasar.

Dedy Pramana. 2013. Pengaruh Kualitas Pelayanan Terhadap Kepuasan
Pengunjung Pada

Perpustakaan Nasional Gianyar.Skripsi. Fakultas Ekonomi Universitas Ngurah Rai Denpasar.

Ghozali, Imam. 2002. Aplikasi Analisis Multivariate dengan Program SPSS. Edisi Kedua. Semarang: Universitas Diponegoro.

Iqbal Hasan. 2002. Metodologi Penelitian dan Aplikasinya. Bandung: Ghalia Indonesia.

Kasmir, 2005.Etika Customer Service. Jakarta: PT RajaGrafindo Persada.

Kotler, Philip dan Gary Armstrong. 2006. Prinsip-Prinsip Pemasaran Edisi XII, Erlangga, Jakarta.

Lovelock, Christopher H, dan Wright Lauren K. 2007.Manajemen

PemasaranJasa. Alih Bahasa Agus Widyantoro, Cetakan Kedua. PT. Indeks. Jakarta.

Lupiyoadi, R. 2001. Manajemen Pemasaran Jasa: Teori \& Praktek; Edisi Pertama, Salemba Empat, Jakarta.

Ratika Dewi. 2016. Pengaruh Kualitas Pelayanan Terhadap Kepuasan Nasabah Pada PT. BPD Bali Cabang Klungkung.Skripsi.

Fakultas Ekonomi Universitas Ngurah Rai Denpasar. 
Rangkuti, Freddy, 2003, Riset Pemasaran, PT. Gramedia Pustaka Utama, Jakarta.

Sugiarto, 2002, Psikologi Pelayanan dalam Industri Jasa, PT. Gramedia Pustaka Utama, Jakarta.

Sugiyono. 2004. Metode Penelitian Bisnis. Cetakan Pertama. Bandung: CV. Alfabeta.
Tjiptono, Fandy dan Gregorius Chandra. 2005. Service, Quality and Satisfaction. Andi, Jogjakarta.

Umar, Husein. 2003. Riset Pemasaran dan Perilaku Konsumen.Jakarta : PT. Gramedia Pustaka Utama.

Zeithaml, Valarie .A and Mary Jo Bitner. 2000. Service Marketing. The McGraw - Hill Companies. 